\title{
Methodology Report \\ Molecular Techniques for Dicistrovirus Detection without RNA Extraction or Purification
}

\author{
Jailson F. B. Querido, ${ }^{1}$ Jon Agirre, ${ }^{2}$ Gerardo A. Marti, ${ }^{3}$ \\ Diego M. A. Guérin, ${ }^{2}$ and Marcelo Sousa Silva ${ }^{1}$ \\ ${ }^{1}$ Centre for Malaria and Tropical Diseases, Instituto de Higiene e Medicina Tropical, Universidade Nova de Lisboa, \\ Rua da Junqueira, 100, 1349-008 Lisboa, Portugal \\ ${ }^{2}$ Unidad de Biofísica (UBF), CSIC-UPV/EHU, Barrio Sarriena S/N, Bizkaia, 48940 Leioa, Spain \\ ${ }^{3}$ Centro de Estudios Parasitológicos y de Vectores (CEPAVE), CCT-La Plata/CONICET-UNLP, No. 584, 1900 La Plata, Argentina
}

Correspondence should be addressed to Marcelo Sousa Silva; mssilva@ihmt.unl.pt

Received 10 January 2013; Revised 15 March 2013; Accepted 21 March 2013

Academic Editor: Zhirong Sun

Copyright (C) 2013 Jailson F. B. Querido et al. This is an open access article distributed under the Creative Commons Attribution License, which permits unrestricted use, distribution, and reproduction in any medium, provided the original work is properly cited.

Dicistroviridae is a new family of small, nonenveloped, and +ssRNA viruses pathogenic to both beneficial arthropods and insect pests as well. Triatoma virus ( $\operatorname{TrV})$, a dicistrovirus, is a pathogen of Triatoma infestans (Hemiptera: Reduviidae), one of the main vectors of Chagas disease. In this work, we report a single-step method to identify $\mathrm{TrV}$, a dicistrovirus, isolated from fecal samples of triatomines. The identification method proved to be quite sensitive, even without the extraction and purification of RNA virus.

\section{Introduction}

Triatoma virus (TrV), together with Solenopsis invicta virus1 , is one of the two members of the Dicistroviridae family pathogenic to insects of medical importance [1]. Because of its horizontal way of transmission and high pathogenicity in populations of triatomines, $\operatorname{TrV}$ has been postulated to be used as a biological control agent for both domiciliated and nondomiciliated vectors of Chagas disease. It replicates within the cytoplasm of gut cells of triatomines [2], causing a high mortality rate, delayed development, and a reduction in the fecundity $[3,4]$. Recently, we have shown that this virus is unable to replicate nor is infective in mice and probably is not infective to other vertebrates, reinforcing the possibility of this virus to be used as a tool in biological control of triatomines transmitters of Chagas disease [5].

Dicistroviruses are characterized for having two open reading frames, ORF1 and ORF2. The ORF2 is responsible for encoding the structural proteins VP1, VP2, VP3, and VP4, which in the case of $\operatorname{TrV}$ have respective masses of $29.7 \mathrm{kDa}$, $28.4 \mathrm{kDa}, 31.8 \mathrm{kDa}$, and $5.5 \mathrm{kDa}[6]$. The viral genome of $\operatorname{TrV}$ is a +ssRNA molecule of 9010 nucleotides [6].
A reliable method for the detection of $\operatorname{TrV}$ by molecular techniques represents an important step towards the identification of insect species being affected by this virus and the analysis of their geographical distribution as well. However, the diagnosis of triatomines in regions where it is difficult to conduct scientific investigation poses a serious challenge. In this study, we present a new method that allows the reduction of costs and time required for the entire process of diagnosis, enabling the detection of $\operatorname{TrV}$ without resorting to RNA extraction, and without running the risk of degrading the RNA during the extraction, purification and storage process.

\section{Materials and Methods}

2.1. Triatoma Virus Purification. The virus purification was made according to $[6,7]$; dry feces coming from infected insects were collected on Whatman filter papers and excised from them using a standard surgery scalpel until $2 \mathrm{~g}$ of material was collected. A buffer composed of $10 \mathrm{mM} \mathrm{NaCl}$, $1 \mathrm{mM} \mathrm{MgCl}_{2}$, and $200 \mathrm{mM}$ citric acid at pH 6 (Lysis buffer) 
was added at a ratio of $100 \mathrm{~mL}$ per gram of dry material. PMSF (N 98.5\%, purchased from Sigma) thawed at $-20^{\circ} \mathrm{C}$ in isopropanol (Merck, GR for analysis) was added up to a final concentration of $1 \mathrm{mM}$. The mixture was homogenized for 5 min using a vortex mixer and then sonicated using a Sanyo MSE Soniprep 150 operating at $10 \mathrm{~s}$ ON/10 s OFF for 20 pulses. The homogenate was thereafter centrifuged in a Kontron T-1170 ultracentrifuge for $45 \mathrm{~min}$ at $20,000 \mathrm{~g}_{\text {avg }}$ using a Beckman SW28.1 rotor. The collected supernatant was then centrifuged for $2.5 \mathrm{~h}$ at $180,000 \mathrm{~g}_{\text {avg }}$ using a Kontron TFT50.38 rotor. The resulting pellet was resuspended overnight in $2 \mathrm{~mL}$ of $10 \mathrm{mM} \mathrm{NaCl}, 1 \mathrm{mM} \mathrm{MgCl}$, and $50 \mathrm{mM}$ Tris at $\mathrm{pH} 7.4$ (NMT buffer) and then loaded on top of a $35 \mathrm{~mL}$ continuous $5 \%-30 \%$ sucrose gradient. The centrifugation was at $100,000 \mathrm{~g}_{\text {avg }}$ for $3 \mathrm{~h}$ in a Beckman SW28.1 rotor. The gradient was fractionated from the bottom to the upper part in $0.5 \mathrm{~mL}$ aliquots that were collected in Greiner 96-well MasterBlocks and sealed thereafter with a silicone-based lid. The gradients were cooled in ice to avoid particle diffusion within them. The individual optical density of each aliquot was then measured at both $260 \mathrm{~nm}$ and $280 \mathrm{~nm}$ using an Implen NanoPhotometer coupled with an LG100 UV-G6786 cell. A baseline correction was performed using equivalent fractions from a control sucrose gradient. After plotting the absorbance profile, selected aliquots were loaded onto $12.5 \%$ polyacrylamide SDS-PAGE gels to check the purity of the samples. Following gradient fractionation, equivalent samples were pooled together and dialyzed overnight against $2 \mathrm{~L}$ of NMT buffer.

2.2. Reverse Transcriptase-PCR. For the RT-PCR, we use different concentration of purified $\operatorname{TrV}$ and feces samples $(66.7 \mathrm{mg} / \mathrm{mL})$, without resorting to RNA extraction. Dry feces coming from infected insects were resuspended in a buffer composed of $10 \mathrm{mM} \mathrm{NaCl}, 1 \mathrm{mM} \mathrm{MgCl}$, and $200 \mathrm{mM}$ citric acid at pH 6 (Lysis buffer). PMSF (N 98.5\%, purchased from Sigma) thawed at $-20^{\circ} \mathrm{C}$ in isopropanol (Merck, GR for analysis) was added up to a final concentration of $1 \mathrm{mM}$. The homogenate was centrifuged in an Eppendorf centrifuge $5417 \mathrm{R}$ for $30 \mathrm{~min}$ at $20,000 \mathrm{~g}_{\text {avg }}$ and was subsequently filtered through a $0.2 \mu \mathrm{m}$. The feces sample was diluted in DEPC-treated water to a final concentration of $33.3 \mathrm{mg} / \mathrm{mL}$. As a positive control, we used viral RNA extracted (Trizol, Invitrogen) from purified $\operatorname{TrV}$ and feces samples. The cDNA synthesis was performed according to cDNA Synthesis Kit Protocol (M-MuLV Reverse Transcriptase, Thermo Scientific). In the PCR reactions were used single primers pairs: $\operatorname{TrV}$ sense: $5^{\prime}$-TCAAAACTAACTATCATTCTGG-3' (nt 7427 to 7448 in $\operatorname{TrV}$ ORF2 sequence) and $\operatorname{TrV}$ antisense: $5^{\prime}$-TTCAGCCTTATTCCCCCCC-3' (nt 8240-8258 in $\operatorname{TrV}$ ORF2 sequence), with an expected product of $832 \mathrm{bp}$ [8], selected from ORG2 region, conserved in dicistrovirus. PCR products were visualized on $1.5 \%$ agarose gels (running for $1 \mathrm{~h}$ at $100 \mathrm{~V}$ ) stained with ethidium bromide, and their sizes were determined by comparison against DNA markers, HyperLadder I (Bioline, UK).

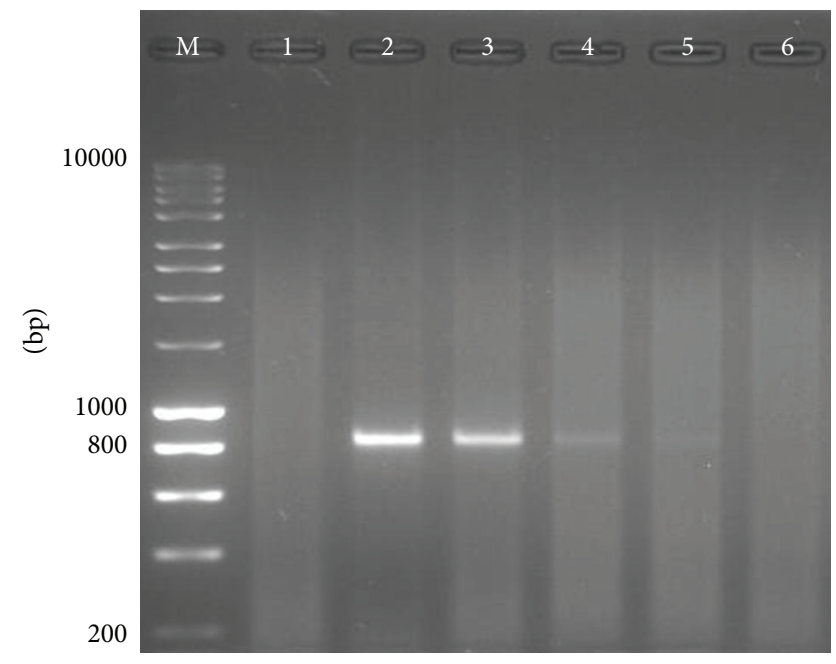

FIGURE 1: PCR products on 1,5\% agarose gel stained with ethidium bromide. M: molecular weight marker 200 bp to 10000 bp (Bioline, UK). Lane 1: negative control, lane 2: 3000 ng of purified TrV, lane 3: $300 \mathrm{ng}$ of purified $\mathrm{TrV}$, lane 4: $30 \mathrm{ng}$ of purified $\mathrm{TrV}$, lane 5: $3 \mathrm{ng}$ of purified $\operatorname{TrV}$, and lane 6: $0,3 \mathrm{ng}$ of purified $\operatorname{TrV}$.

\section{Results and Discussion}

To obtain the cDNA, we used full genome $\operatorname{TrV}$ particles without RNA extraction. We used a concentration range between 3,000 and $0.3 \mathrm{ng}$ of virus, being this concentration measurement based on the viral proteins, diluted in DEPCtreated water. The cDNA amplifications were performed using the selected primers pairs mentioned above. We obtained amplification until a minimum concentration of 3 ng of viral particles (Figure 1).

To initiate the cDNA synthesis, we mixed $5 \mu \mathrm{L}$ of viral samples (5, 3, and $1 \mu \mathrm{L}$ for feces samples) with $100 \mathrm{pmol}$ of Oligo (dT), incubated first at $65^{\circ} \mathrm{C}$ for $5 \mathrm{~min}$ and then at $4^{\circ} \mathrm{C}$ for $5 \mathrm{~min}$. During the contact with the host cells, the virus released the genome. In vitro, this process may occur by varying certain environmental conditions such as $\mathrm{pH}$ or temperature $[8,9]$. Incubating the virus at a temperature above $65^{\circ} \mathrm{C}$ will cause RNA release [8]. However, such temperature and time of incubation should not be too long because $65^{\circ} \mathrm{C}$ is close to the melting temperature of RNA. The results indicate that viral RNA can be detected in feces samples, after a single centrifugation and filtration step (Figure 2). These results reinforce the applicability and reproducibility of the method presented in the previous paragraph.

When we compare the result of RT-PCR from the samples analysed directly without resorting to RNA extraction to the samples where RNA extraction was proceeded, we can see that there is no significant difference between these two methods, which indicates that the method proposed here is a good alternative to the method traditionally used.

\section{Conclusions}

The method proposed in this study allows the detection of dicistrovirus by RT-PCR without resorting to RNA 


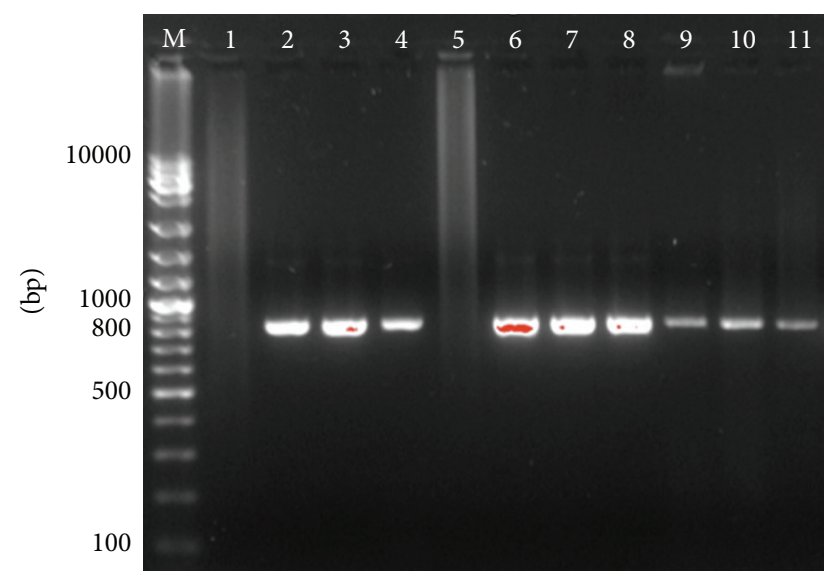

FIGURE 2: PCR products on 1,5\% agarose gel. M: molecular weight marker $100 \mathrm{bp}$ to $10000 \mathrm{bp}$ (Jena Bioscience, Germany). Lane 1: negative control, lane 2: $5 \mu \mathrm{L}$ of viral RNA (from $3000 \mathrm{ng}$ of purified $\operatorname{TrV}$ ), lane 3: $5 \mu \mathrm{L}$ of viral RNA (from $300 \mathrm{ng}$ of purified $\operatorname{TrV}$ ), lane 4: $5 \mu \mathrm{L}$ of viral RNA (from $30 \mathrm{ng}$ of purified $\operatorname{TrV}$ ), lane $5: 5 \mu \mathrm{L}$ of viral RNA (from $0,03 \mathrm{ng}$ of purified $\mathrm{TrV}$ ), lane $6: 5 \mu \mathrm{L}$ of viral RNA (from $1 \mathrm{mg}$ of feces), lane $7: 5 \mu \mathrm{L}$ of viral RNA (from $0.5 \mathrm{mg}$ of feces), lane 8: $5 \mu \mathrm{L}$ of viral RNA (from $0,25 \mathrm{mg}$ of feces), lane $9: 5 \mu \mathrm{L}$ of feces samples (without RNA extraction), lane 10: $3 \mu \mathrm{L}$ of feces samples (without RNA extraction), and lane 11: $1 \mu \mathrm{L}$ of feces samples (without RNA extraction).

extraction, which reduces the cost associated with this method and the risk of RNA degradation during the process of RNA extraction, and it is swimmingly reproducible in a low-budget laboratory. Moreover, this study provides new facts about the thermostability of the TrV structure.

\section{Acknowledgments}

The authors are grateful to Rubén Sánchez-Eugenia and Sonia López (UBF) for their technical assistance in $\operatorname{TrV}$ purification. Jon Agirre was supported by a UPV/EHU contract (UPV-IT-461-07). Gerardo A. Marti is a researcher of the CONICET, Argentina. Diego M. A. Guérin is researcher of the Fundación Biofísica Bizkaia and was partially supported by Grants SAIOTEK, Gobierno Vasco (GV), and MICINN, Spain. This work was partially supported by Acción Especial AE-2009-1-21, from the GV, Spain, and CYTED 209RT0364 action (RedTrV: http://www.redtrv.org/), both granted to Diego M. A. Guérin.

\section{References}

[1] B. C. Bonning and W. A. Miller, "Dicistroviruses," Annual Review of Entomology, vol. 55, pp. 129-150, 2010.

[2] O. A. Muscio, J. L. la Torre, and E. A. Scodeller, "Characterization of Triatoma virus, a picorna-like virus isolated from the triatomine bug Triatoma infestans," Journal of General Virology, vol. 69, no. 11, pp. 2929-2934, 1988.

[3] O. A. Muscio, J. L. la Torre, M. A. Bonder, and E. A. Scodeller, "Triatoma virus pathogenicity in laboratory colonies of Triatoma infestans (Hemiptera: Reduviidae)," Journal of Medical Entomology, vol. 34, no. 3, pp. 253-256, 1997.
[4] G. S. Rozas-Dennis and N. J. Cazzaniga, "Effects of Triatoma virus $(\mathrm{TrV})$ on the fecundity and moulting of Triatoma infestans (Hemiptera: Reduviidae)," Annals of Tropical Medicine and Parasitology, vol. 94, no. 6, pp. 633-641, 2000.

[5] J. F. B. Querido, J. Agirre, G. A. Marti, D. M. A. Guérin, and M. S. Silva, "Inoculation of Triatoma Virus (Dicistroviridae: Cripavirus) elicits a non-infective immune response in mice," Parasites \& Vectors, vol. 6, article 66, 2013.

[6] J. Agirre, K. Aloria, J. M. Arizmendi et al., "Capsid protein identification and analysis of mature Triatoma virus ( $\mathrm{TrV}$ ) virions and naturally occurring empty particles," Virology, vol. 409, no. 1, pp. 91-101, 2011.

[7] G. A. Marti, E. Neumann, D. M. A. Rey et al., "AC-ELISA and RT-PCR assays for diagnosis of Triatoma virus ( $T r V)$ in triatomines (Hemiptera: Reduviidae) species," Archives of Virology, vol. 153, pp. 1427-1432, 2008.

[8] J. Agirre, G. Goret, M. LeGoff et al., "Cryo-transmission electron microscopy reconstructions of triatoma virus particles: a clue to unravel genome delivery and capsid disassembly," Journal of General Virology, 2013.

[9] M. Bostina, H. Levy, D. J. Filman, and J. M. Hogle, "Poliovirus RNA is released from the capsid near a twofold symmetry axis," Journal of Virology, vol. 85, no. 2, pp. 776-783, 2011. 

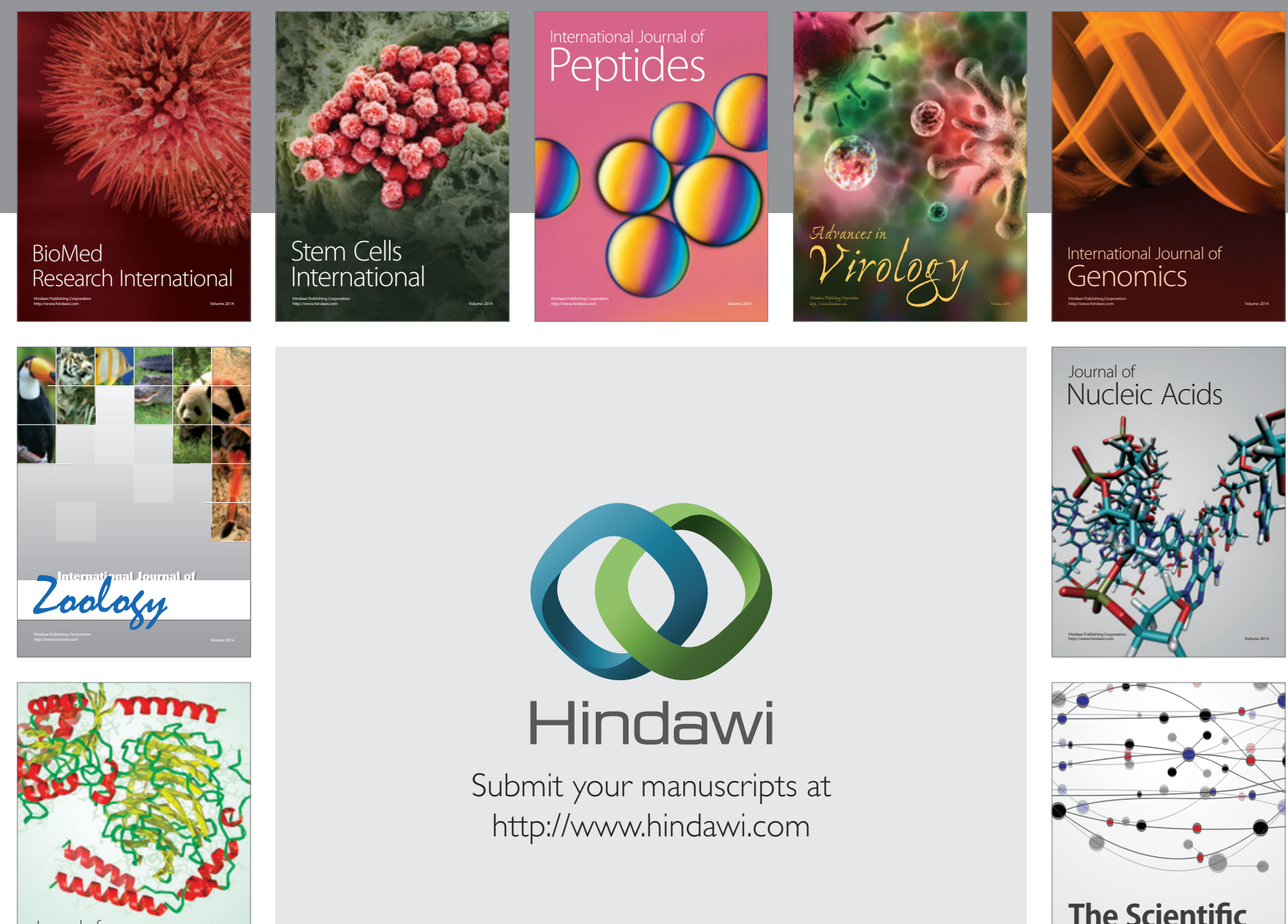

Submit your manuscripts at

http://www.hindawi.com

Journal of
Signal Transduction
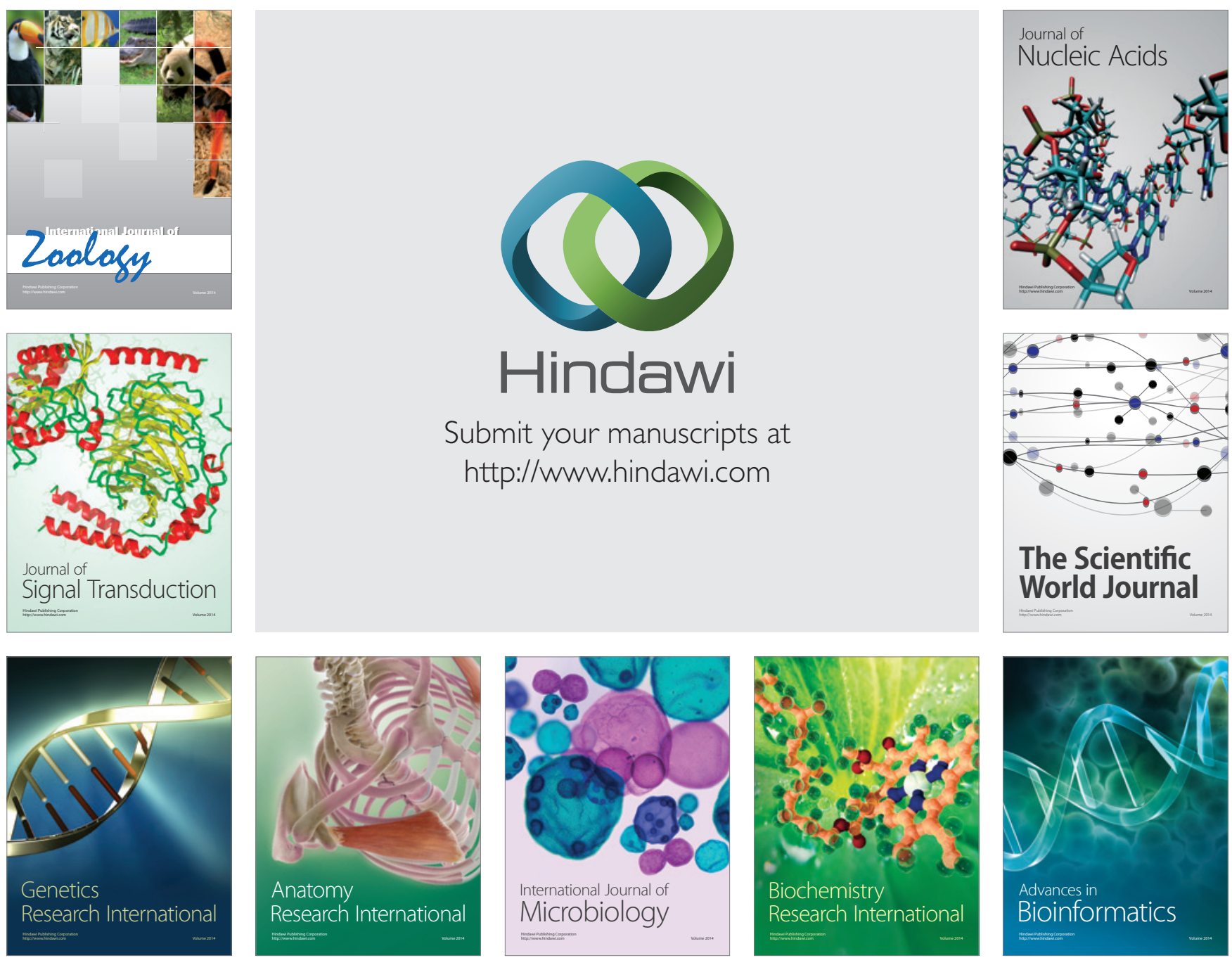

The Scientific World Journal
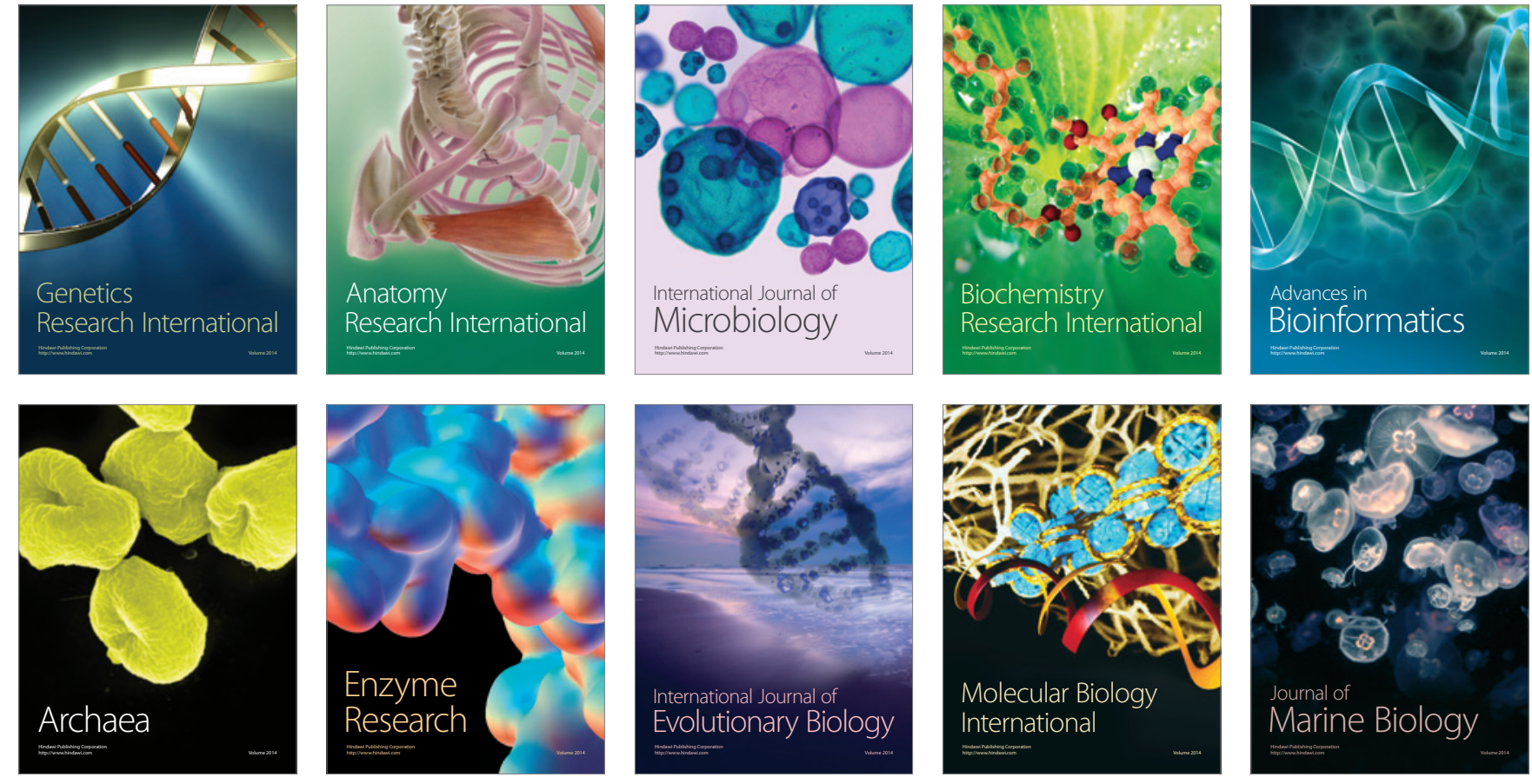